\title{
THE ADEQUACY OF THE INTERNATIONAL COOPERATION MEANS FOR COMBATING CYBERCRIME AND WAYS TO MODERNIZE IT
}

\author{
Farouq Ahmad Faleh Al Azzam \\ farouq.azzam@hotmail.com \\ Assistant Professor of Law at Jadara University (Jordan)
}

\section{Abstract}

The era of scientific and technological development has witnessed an extensive use of Internet and electronic devices in various aspects of life. This widespread use has increased security risks, privacy and cyberattacks that threaten both individuals and States. This kind of crime is difficult to prevent as a result of the constant digital technological advances and globalization.

There is a growing concern among States and government agencies that such intrusions could critically affect the security and the economics of any State. Combating this kind of crime requires international cooperation. Therefore, many States have called for the need to define cybercrime and to hold conventions to adopt effective legal framework to combat and restrict the progress of cybercrime worldwide.

This study concluded that cooperative mechanisms are needed to coordinate and unify joint efforts and to modernize means of combating cybercrime using the latest techniques. In addition, it is necessary to upgrade existing mechanisms and develop other methods to achieve various aspects of cooperation.

\section{Keywords}

Cybercrime, international security cooperation, countering organized transnational crime, criminal organized crime, modernizing means to counter cybercrime.

\section{How to cite this article}

Al Azzam, Farouq Amhad Faleh (2019). "The adequacy of the international cooperation means for combating cybercrime and ways to modernize it". JANUS.NET e-journal of International Relations, Vol. 10, N.0 1, May-October 2019. Consulted [online] on the date of the last visit, https://doi.org/10.26619/1647-7251.10.1.5

Article received on October 25, 2018 and accepted for publication on February 20, 2019 


\title{
THE ADEQUACY OF THE INTERNATIONAL COOPERATION MEANS FOR COMBATING CYBERCRIME AND WAYS TO MODERNIZE IT
}

\author{
Farouq Ahmad Faleh Al Azzam
}

\section{Introduction}

In an increasingly globalized and electronic world, the extent of computer-related crime within and across countries is affecting a huge sector of national and international society. Nowadays, many private and local sectors are using the networks to attain their objectives, whether they are social, economic, financial, or political activities. These practices have encouraged the appearance of cybercrime.

Cybercrime is a crime that involves the use of digital technologies to commit an offence, using computing and communication technologies to pursue illegal activity. These activities involve attacking information centers and data systems, theft, online transaction fraud, Internet sale fraud and conducting Internet malicious activities, such as viruses, worms and third-party abuse like phishing and email scams. Additionally, it may pose a serious threat to governments and their confidential information by accessing their security systems and data.

Therefore, to combat cybercrime, governments should use modern scientific means and joint international strategic planning through formal cooperation at all levels, considering the general security interest above all others and the need to overcome the differences they face, such as the principle of sovereignty, since this principle is a fundamental issue that stands in the way of this needed international cooperation.

International judicial cooperation is the fundamental base to combat a crime in its various dimensions, such as international information terrorism, cybercrime and other offenses committed by criminal organizations or legal persons. Thus, countries should seek to create a legal base that enhances joint international cooperation against cybercrime and sets enforceable laws.

To address this issue, we need to clarify the current mechanisms used to fight cybercrime, consider ways of improvement and suggest solutions. The researcher has divided this paper into two topics. The first deals with the aspects of international cooperation to combat transnational organized crime. The second topic examines ways to modernize mechanisms for international cooperation in combating crime. 


\section{The First Topic: the aspects of international cooperation in combating transnational organized crime}

Cybercrime is still a modern concept as it is associated with contemporary technology innovations (the World Wide Web and the Internet). It is defined as any criminal activity that takes place on or over the medium of computers or Internet or other technology recognized by the Information Technology Acts. It is committed by technically skilled criminals to achieve their illegal intentions.

The United Nations defined cybercrime ${ }^{1}$ at the Tenth Congress on Crime Prevention and Treatment of Offenders in Vienna in 2000 as: any crime that can be committed by a computer system, a computer network or over the medium of computers, and that includes, in principle, all crimes that can be committed in an electronic environment ${ }^{2}$. Electronic crimes are also divided into several types, for example, crimes that are committed against individuals, properties and governments. It can also be defined as a crime that knows no boundaries.

Cybercrime aims to access confidential information illegally in order to steal, delete or change the data stored in institutions and government agencies. It also accesses personal data to blackmail individuals, as well as for moral and political objectives ${ }^{3}$. Therefore, States have been interested in the concept of cybercrime and in achieving the capacity to address transnational crime, making efforts to fill the legal gap that criminal organizations have penetrated ${ }^{4}$.

Generally, mutual legal assistance in criminal matters is an effective mechanism to deal with crimes because of its profound impact on criminal proceedings and its role in reconciling the right of the State to exercise its criminal jurisdiction within its territorial boundaries and its right to penalty ${ }^{5}$.

This research illustrates, in section $I$, the role of the United Nations in combating cybercrime and, in section II, the role of the Budapest Convention in addressing cybercrime.

\section{Section I. The role of the United Nations in combating cybercrime.}

The United Nation International and regional conventions, as well as the Arab treaties, have played a significant role in confronting international crime in general ${ }^{6}$, such as the Tokyo Convention on Offenses and Certain Other Acts Committed on Board Aircraft of 14 September 1963 and the Hague Convention for the Suppression of Unlawful Seizure of Aircraft of 16 December $1970^{7}$.

Zuhair, Haj Tahir, Mechanisms of Crime Prevention and Control, Master of Criminal Law, Faculty of Law, University of Algiers, Algiers, 2013, p. 95.

Halabi, Khalid Ayad, Investigation of Computer and Internet Crimes, Dar Al-Thaqafa, Jordan, 2011, p.11. Journal of Information Technology, Department of Information Systems, Jordan, 2015.

Al-Qahtani, Faleh Muflih, 2008, Role of International Cooperation in Combating Overseas Drug Trafficking, Master Thesis, Naif Security University, p. 12.

5 Surour, Ahmed Fathi, 1993, mediator in the Code of Criminal Procedure, Modern Printing House, Egypt, p. 82.

6 Al-Shawabkeh, Mohammed Amin, Computer and Internet Crimes, Jordan, Dar Al-Thaqafa for Publishing and Distribution, 2004, pp. 140-144.

7 See Articles 22, 23, 24, 30, 31.33 of the Arab Convention against Cybercrime of 2010, amended in 2014. 
The United Nations Organization has a direct role on improving the image of international cooperation in its various manifestations by signing international treaties and conventions that foster the cooperation of States among themselves to combat crime. Article $17^{8}$, entitled "Mutual legal assistance", is the most important source of international criminal cooperation in this area. Article 1 specifies the scope of cooperation to provide the requested State the greatest amount of mutual assistance in investigations and trial proceedings.

Article 2 covers rules of witness testimony, the hearing of persons, assisting in the investigation, the communication of authentic documents and records and the provision of certified copies, including bank records, financial records or corporate or business records ${ }^{9}$. A model treaty on mutual assistance in criminal matters was prepared based on United Nations standards and norms in crime prevention and criminal justice. It was adopted by General Assembly resolution 45/1117 of 14 December 1990 and implemented by the Eighth United Nations Congress on the Prevention of Crime and the Treatment of Offenders ${ }^{10}$. The preamble to the Model Treaty states the desire to uphold the objectives of justice, to restore social stability to criminals and to promote the interests of victims of crime (article 1, paragraph 1 ).

In order to achieve the required results of legal cooperation, the Group of Experts on the strategy for combating organized crime requested that the principle of dual criminality should be abandoned as a condition for mutual assistance. They called for flexibility and speed in the exchange of all available assistance. States should coordinate their efforts to counter transnational criminal organizations and strip them of the proceeds of crime in the event of a conviction, since they have an effective impact on organized crime. This was confirmed by the European Union in 1994 in its call for combating crime to be eliminated from its sources through activating judicial cooperation.

The United Nations Declaration on Crime and Public Security as a fundamental document for cooperation against organized crime stated in article 1 that: "Member States shall protect the security and well-being of their citizens and other persons within their jurisdiction by effective national measures against transnational crime, including organized crime, illicit trafficking, organized trafficking in persons, crimes of terrorism and laundering of the proceeds of serious crimes, and undertake to cooperate together in those efforts." Article 2 of the United Nations Declaration on Crime and Public Security states: "Member States shall promote bilateral, multilateral, regional and global cooperation and assistance in the implementation of laws, including, as appropriate, mutual legal assistance arrangements, or otherwise responsible, and to ensure that they are prosecuted, to ensure effective cooperation between law enforcement authorities and other competent authorities"11.

Generally, cooperation and coordination are the main pillars in crime prevention, which does not stand in the State of origin but extends to other countries. Thus, the international community has confirmed the importance of legal assistance by stating

Suleiman, Mohammed Ibrahim Mustafa, 2006, Terrorism and Organized Crime, Dar Al Talai, Egypt, p. 103. Bassiouni, Mohamed Sherif, 2004, Transnational Organized Crime, F I, Dar al-Shorouk, Egypt, p. 45.

10 Waly, Ali, 1981, echoes of the Sixth United Nations Congress on the Prevention of Crime and the Treatment of Offenders, Journal of Justice, No. 27, issued by the Ministry of Justice, Abu Dhabi, p. 146.

11 United Nations Documents of the General Assembly, 1995, 51st Session, United Nations Declaration on Crime and Security, p. 2. 
different legal means to impose joint laws enhancing crime prevention, for example, judicial delegation and foreign judgments.

\section{A. Judicial Delegation}

Judicial delegation results from the duties or commitments imposed by public international law on the United Nations ${ }^{12}$, under which judicial authorities are required to take a specific action, to conduct investigations in the interest of the competent judicial authority of the requesting States taking into account respect for universally recognized human rights and freedoms. In return, the requesting State undertakes to recognize reciprocity and respect for the legal consequences of the requested State ${ }^{13}$.

In accordance with article 6 of the Convention on Declarations and Jurisdictions, judicial delegation means that: Each State bound by this convention shall request any State to initiate in its territory any judicial proceedings relating to a case under consideration in accordance with articles 7 and 8 . The aim of the judicial delegation is to transfer procedures in criminal matters to counter developments in criminal phenomena and to overcome difficulties and obstacles to the conduct of criminal proceedings on extraterritorial issues, where judicial delegation exists in national laws, international conventions and in the principle of reciprocity.

\section{B. Foreign Judgments}

One of the concepts that must be overcome in order to support international cooperation is the non-applicability of foreign judgment, on the grounds that criminal justice is in fact a manifestation of the sovereignty of the state and its right to punish ${ }^{14}$. However, it should not be limited to the negative consequences of a foreign criminal judgment on the inadmissibility of a person being tried twice. Criminal jurisprudence calls for the need for precedence to prevent the impunity of perpetrators and ensure the requirements of justice. In accordance with the spent efforts, several international conventions decided to implement judicial decisions ${ }^{15}$, including criminal provisions, such as the one in 1952 among members of the European Community, and to oblige States Parties to implement criminal and other provisions unless one of the specific cases fails to implement it. The same statement is made in article 3 of the Convention against Illicit Traffic in Narcotic Drugs and Psychotropic Substances of 1988. The Convention on the Suppression of Transnational Organized Crime has focused on mutual assistance as a major means of cooperation to confront criminal organizations that conduct various forms of criminality of an international character. Article 6 states that States Parties must help and coordinate themselves to carry out actions regarding any of the offenses covered by the provisions of the convention, including the collection of evidence, guarantees for the protection of witnesses and the transfer of proceedings. The draft Convention submitted by Poland in its tenth article emphasized that States should cooperate with each other and be flexible

12 Sugheer, Jamil Abdel Baki, Procedural Aspects of Internet Related Crimes, Dar al-Nahda, Egypt, 2001, p. 83.

13 Al-Harouni, Hazem, 1988, "International Judicial Appeal", National Journal,3rd issue, p. 21.

14 Al-Laqli, Mahmoud Mustafa, 1991, Judicial Links, University Library House, Egypt, p. 132.

15 Al-Ghareeb, Muhammed Eid, 1988, Penal Code, General Section, General Theory of Crime, II, Dar Al-Alam, Lebanon, p. 199. 
and expeditious in the exchange of legal assistance ${ }^{16}$, in accordance with their national procedural laws concerning investigation, evidence collection, prosecution and the conduct of judicial proceedings. In the second paragraph of the same article, reference was made to the provision of legal assistance in the area of information covered by bank secrecy.

Article 14 of the International Convention against Transnational Organized Crime also ensures the need to document legal assistance in various areas, "investigations, followup, judicial proceedings" when any of the offenses covered by its provisions are concerned. The same article identifies the cases and how to apply for legal assistance, including the assets of relevant documents and records, and bank or financial records, corporate records, disclosure of proceeds of crime, property, tools or other objects derived from criminal activities, or to trace their impact to obtain the evidence necessary to charge the perpetrators ${ }^{17}$.

To overcome and simplify the legal hindrances to the absence of a bilateral or multilateral treaty governing mutual legal assistance between requesting and requested States, the Convention against Organized Crime was considered as a legal basis for the exchange of assistance so that it would not be possible to fall under the double criminality requirement (Paragraph 6) or banking secrecy (Paragraph 5). For the purposes of this Convention, the offenses covered by the provisions of financial crimes, political offenses or humanitarian motives are not considered (Paragraph 17 of the same Article), which reflects the desire of the international criminal policy-makers to deal with this crime that threatens the whole international community.

The strategy formulated by the Naples Declaration against Organized Crime ensured the recognition of national judgments in view of the significance of the criminal record when deciding criminal cases ${ }^{18}$, as it indicates the seriousness of the perpetrator and the appropriate punishment commensurate with the seriousness of the crime. This Declaration pledged that the foreign judgment of the original crime would have the authority to prosecute the partner, especially since the majority of criminal legislation did not define a special law on organized crime that placed the activity of a partner in crime at the same level of the activity carried out by members of the criminal organization. This is the reason why the Italian judiciary has decided to hold the external partner accountable for the crimes committed by the members of the criminal group.

The international dimension of cybercrime has made it compulsory for the international community to find more appropriate means to fight it according to its nature, narrowing the legal gaps that the perpetrators have exploited to evade punishment and to spread their activities to different regions of the world. The ideal criminal policy will not achieve the desired purpose unless all have homogeneous criminal, preventive and executive measures. To that effect, a number of mechanisms of a technical and administrative nature have been adopted to take advantage of the technological advances and knowledge of the source of information. This will be explained by the presentation of two forms of technical cooperation, as follows:

16 Basha Faizah, Younus, 2001, organized crime under international conventions and national laws, Dar alNahda al-Arabiya, Egypt, p. 221.

17 See Proceedings of the Seventh United Nations Congress on the Prevention of Crime and the Treatment of Offenders 1985, p. 42.

18 Bassiouni, Mohamed Sherif, Op. Cit, P. 97. 


\section{Firstly: Information Exchange}

It is well-known that the modern era is witnessing technological evolution, especially in the field of information, which has forced the international community to give the exchange of information the greatest importance as a means to fight crime in general and cybercrime in particular. It provides reliable and confidential information to support law enforcement agencies in all fields, including the activity of criminal organizations and sources of funds.

Therefore, the Sixth United Nations Congress on the Prevention of Crime and the Treatment of Offenders suggested the development of a systematic exchange of information as a key element of the International Plan of Action for the Prevention and Control of Crime and recommended that the United Nations should establish an information base to inform States Parties of global trends in crime ${ }^{19}$. Thus, cooperation in matters of information crime should support the use of information exchange systems among Member States and the provision of bilateral and multilateral technical assistance to Member States, using training on law enforcement and the international criminal justice treaty.

The centralization of information should not hinder the dissemination and exchange of information among States after it has been collected, studied and dealt with in a way that enables them to be used at the investigative and trial stage, to facilitate pursuing suspects, whether individuals or bodies. That was confirmed by the European Union's Schengen Agreement through the creation of an integrated system for the exchange of information.

Hence, information prevention is an essential element, a basic base to combat information crime, and a way to ensure the creation of an effective counterfeiting system. On this basis, drafts of the Convention against Organized Crime regarding information exchange has proved to be a preventive mechanism for combating this crime. Article 1 , paragraph 2 of the draft framework convention declares that State Parties shall facilitate the exchange of information on all aspects of the criminal activity of persons involved in organized crime.

\section{Secondly: Exchange of expertise and technical assistance}

To achieve integration with the general trend of computerization of criminal justice operations, and to develop and analyze information in a manner that serves the objectives of modern criminal policy to combat crime in general, some procedures should be taken into consideration. These include exchanging administrative elements, enhancing the capacity of justice agencies, analyzing and disseminating available data on crime and the innovative, traditional and non-traditional mechanisms used to combat crime. Moreover, emphasis should be placed on new methods, such as technical cooperation support and the provision of extensive advisory services to cover all areas, like the concealment of funds, to counter money laundering and to deprive criminal organizations of the proceeds of crime. This is because preventive policy will remain

19 Qarzan Mustafa, International Politicians for Combating Cyber Crime, published research on the legal organization of the Internet and cybercrime, University of Xi'an Ashour, University of Djelfa, 2009, p. 7. 
inadequate unless it controls all elements of the alleged criminal behavior. Bilateral and multilateral technical assistance can be provided to Member States by implementing international exchange programs on law enforcement training and international criminal justice treaties. In this case, the legislative authorities of any State must amend the Criminal Procedure Code to legitimize them to be consistent with the nature of the crime in its various new dimensions. In order to achieve this, a special law must be created to cover all legal, substantive or procedural aspects, without being bound by the general rules that may sometimes prevent criminal justice from achieving its purposes ${ }^{20}$.

\section{Section II: The role of the Budapest Convention in the fight against information crime.}

The Budapest Convention was signed in late 2001. It aimed at combating cybercrimes by harmonizing laws and providing a framework for international cooperation among States Parties to the treaty. It also illustrated the international collaboration mechanisms in terms of controlling cybercrime. More than 30 states ratified the convention in $2001^{21}$ to restrict illegal electronic accounts and the abuse of information networks. Although the Budapest Convention is a European-originated treaty, it has an international character. It was ratified by non-members of the Council of Europe, such as Canada, Japan, South Africa, and the USA because it is open and allows the accession of other countries other than those from the European Community (according to article 48 of the Budapest Convention) ${ }^{22}$.

After examining the 48 articles of the convention, the researcher found that it confirms the need to take legislative measures to combat computer crimes through several procedures and recommendations. The Convention was therefore considered a major reference to subsequent conventions and domestic laws of some States ${ }^{23}$.

The Budapest Convention focuses on three basic elements: The first is the importance of substantive legislative measures. The second element is the importance of procedural legislation appropriate to the nature of the crime. The third is the importance of international and regional co-operation in the field of cybercrime. All these elements are referred to in four sections.

The authors of this treaty have identified the general framework of these crimes to be illegal access to data systems, misuse of accounts and information fraud. The treaty, thus, specified conditions to identify these actions legally.

Finally, it can be said that the Budapest Convention respects human rights and prevents their exposure to crimes committed through the Internet, and it does not conflict with the Universal Declaration of Human Rights.

The Budapest Convention established new measures to combat cybercrime. These are based on the following important principles: The obligation of States Parties to the Convention to adopt legislation and other measures if necessary in accordance with their

Al-Laqli, Mahmoud Mustafa, Op cit, p. 123.

21 Arian, Mohamed Ali, Computer Crimes, New University House, Alexandria University, Egypt, 2011, p. 25.

22 Zuhair, Haj Tahir, Mechanisms of Crime Prevention and Control, Master of Criminal Law, Faculty of Law, University of Algiers, Algiers, 2013, p. 102.

23 Attia, Tareq Ibrahim, Information Security - The Legal System of Information Protection, New University House, Egypt, 2009, p. 343. 
domestic law and legal framework by establishing special criminal powers and procedures.

The Budapest Convention stipulated some new criminal procedures to combat cybercrime, as follows:

$\Rightarrow \quad$ To ensure the expeditious preservation of stored data - this procedure is contained in Articles 16 and 17 of the Convention, and is intended to preserve, store and protect the foregoing information from anything that may corrupt it or damage its quality ${ }^{24}$.

$\Rightarrow \quad$ To preserve and collect participants' information: this action is aimed at criminal investigation to determine the identity of the computing crime perpetrator.

$\Rightarrow \quad$ To search and seize stored computer data: It is provided for in Article 19 of the Convention and is intended to search and access the data after obtaining official permission for inspection by its competent authorities ${ }^{25}$. Article 31 regarding the search for data stipulates that additional procedural provisions must be in place to ensure access to the data to be used as evidence.

$\Rightarrow \quad$ Eavesdropping: a new procedure in the framework of the procedural control of information crime.

$\Rightarrow \quad$ International cooperation: to activate the previous procedures, article 23 stipulated that parties shall co-operate internationally to the widest possible extent ${ }^{26}$.

$\Rightarrow \quad$ To decrease the challenges facing information exchange and evidence at international levels.

The Budapest convention has a binding structure, as Article 2 specified that each Party shall adopt such legislative and other measures as may be necessary to establish criminal offences under its domestic law, when committed intentionally.

Accordingly, the Budapest Convention is considered the basis of an international agreement that represents a unified vision on technical or cybercrime, as it creates legislative procedures to handle criminal acts. Thus, in this century, it is not acceptable to deal with cybercrimes using traditional mechanisms that cannot be adapted.

\section{The Second Topic: ways to modernize the mechanisms and methods of international cooperation in combating cybercrime}

There is no doubt that improving the employee level of performance is a requirement of any professional development in general, and in the field of law enforcement particularly. This is because any employee may be exposed to financial temptations from criminal organizations to facilitate their illegal work. This was stipulated in the Caracas Declaration of the Sixth Conference, which confirmed the need to improve the conditions of employees and raise their educational and technical level in the administration of the

24 Omar Abul-Fotouh Abdel-Azim Hamami, Criminal Protection of Electronic Information, Dar Al-Nahda AlArabiya, Egypt, p. 314.

25 Hilali Abdullah Ahmed, Budapest Convention on Combating Cyber Crime, Dar al-Nahda al-Arabiya, Egypt, 2011, p. 192.

26 Hilali Abdullah, Op. Cit, p. 298. 
criminal justice system so that they can carry out their duties away from personal interests. Article 10 of the Caracas Declaration entitled "Training on law enforcement" of the draft Convention on the Suppression of Transnational Organized Crime stipulates that: "Each State Party shall, to the extent it may be necessary, initiate, develop or improve specific training programs for its law enforcement personnel, including prosecutors, investigating magistrates and customs personnel, and other personnel charged with the prevention, detection and control of the offences covered by this Convention".

Accordingly, it can be said that the process of modernizing the international cooperation mechanisms in criminal law begins with a first step that aims at developing national laws in a more comprehensive and flexible way that correspond to international legislation of combating systematic crime. On the other hand, it is necessary to formulate an integrated theory that would benefit from technological development in evidencegathering and information-sharing procedures to address criminal organizations that operate in a scientifically informed manner to disperse and discard evidence. Judicial cooperation should also be developed at its various stages, including the implementation of sentences. Therefore, it is necessary to identify the position of the executive policy established by the parties and review the role of the bodies based on the implementation of specialized laws and quality thereof ${ }^{27}$.

It is obvious that cybercrime is a challenge for national, regional and international criminal justice agencies alike, because they lack mechanisms and methods that can address the nature of this crime, which can easily change because of the flexibility of its structures, the precision of the organizations involved and the close cooperation among their members. As a result of these challenges, the Luxembourg Summit approved to establish Europol as a central office for criminal police in the EU under the Maastricht Convention. The Europol Agreement was signed in Brussels on June 26,1995 by ambassadors of 15 EU Member States and aims at ensuring maximum cooperation, sharing and exchanging information in all fields as well as facilitating communication among Member States by establishing focal points and assigning one port for all related services ${ }^{28}$. The European Union has also authorized the Europol Commission to include national authorities in their planned policy to combat organized crime, prepare procedures in the field of police, customs and judicial investigations and to work with their authorities as an integrated unit. One of its most crucial powers is to permit Member States to intervene in the investigations they have initiated and to attend the investigation sessions on organized crime. The Europol is authorized to analyze information related to organized crime and its criminal practices in its various forms, including those related to criminal organizations of the Mafia type, such as the Sicilian, Japanese, Korean, and Russian ones, and investigate their economic and commercial penetration ${ }^{29}$.

The European Union still recommends the expansion of Europol's jurisdiction and is establishing a communication point between it and third-world countries, including Jordan, to ensure the adoption of a unified counter-terrorism policy against various forms of organized crime, including cybercrime. This is in addition to coordinating police

27 Basha Faizah, Younus, Op cit, p. 285.

28 Ghattas, Iskandar, Without a Year Publication, Arab Symposium on International Judicial Cooperation in the Criminal Field in the Arab World, Dar Al-Qalam, Lebanon, p. 22.

29 Al-Basha, Faizah, Younus, Op. Cit, p. 354. 
operations, documenting the exchange of information and directing the ongoing communication to develop judicial cooperation.

Therefore, all countries should adopt a unified policy to reduce the security deficiencies in dealing with organized crime in its various forms, especially cybercrimes. This should be done through the establishment of a coordinated program, developing more efficient mechanisms and purging criminal justice agencies during all stages of the proceedings, which begins with the collection of evidence and ends with prosecution.

Today, security and judicial cooperation has become one of the most significant elements of national and regional strategies that unify the practical procedures of the executive bodies and work towards close co-operation among members.

Third-world countries are missing this kind of cooperation and we will show real examples of this type of assistance (the Schengen Agreement, the Maastricht Agreement and the Amsterdam Agreement), as follows:

\section{A. The Schengen Agreement:}

The Schengen Agreement was signed in 1985 with the aim of deepening cooperation among the countries of the European Union in various fields, including harmonization of legislation, judicial cooperation, elimination of border controls, and achieving more freedom and security. In 1990, the Supplementary Protocol included 142 articles. In the third chapter, it referred to police and security cooperation. The regulation ratified an information system, known as SIS $^{30}$.

The system provides information about individuals and objects through border control. The SIS system allows the justice agencies of the States Parties to freely move from one State to another in the territory of the European Community to monitor and investigate serious crimes $^{31}$. The agreement established a special media system for the publication of all orders issued for the inspection of persons or vehicles on the basis of computers or other means of communication, so that the border police can work together and strengthen official cooperation in joint border crossing points.

\section{B. Maastricht Agreement:}

This agreement was concluded in 1992 in order to fill the judicial vacuum and address organized crime. It grants the States Parties to the agreement a mechanism for security cooperation. Article 1 of the Agreement stated that: it was concluded for the purpose of achieving the objectives of the European Union and matters of common concern, especially the freedom of the movement of persons and laws governing the crossing of borders, monitoring border crossing, immigration system, conditions of illegal residence, international fraud, and strengthen judicial cooperation in civil and criminal matters. Furthermore, it concerns the cooperation of customs department and police to ensure

30 Nabhan, Mohamed Farouk, 1992, Towards a unified Arab strategy to combat organized crime, University House, Jordan, p. 194.

31 Darwish, Abdel Kareem, without a Year of publish, Transnational Organized Crime, Al-Ma'aref Establishment, Egypt, p. 123. 
prevention of terrorism and other forms of serious crimes with an international dimension ${ }^{32}$.

\section{The Amsterdam Convention}

In 1997, the European Union implemented Maastricht's mechanisms for the protection of security and the establishment of justice and freedom. This agreement was signed on October 2, 1997. Article 1 confirmed the informal cooperation between the police and judicial bodies to confront terrorist and transnational crimes. On April 12, 1996, a meeting of the Ministers of the Interior, Justice and Finance of the Member States was held to formulate operational mechanisms recommending the increase in the effectiveness of the counter-crime measures. The agreed points reflected the authorities' concern about the effects of cybercrime. In order to improve the cooperation between police agencies, INTERPOL was entrusted with the achievement of the objectives set by this meeting. These objectives are as follows:

1. To ensure the joint assistance and development of the criminal police authorities in a broader context and within the framework of the laws of the various States in favor of the protection of human rights.

2. To establish centers that can effectively contribute to preventing and deterring violations of common laws, and develop these centers without interfering in any political, military or religious-racist activity to impose laws, regardless of it being an exchange of information, investigation, prosecution or use of technology and organization ${ }^{33}$.

3. Interpol to play a key role in the exchange of information and in warning banks and financial institutions against suspicious transactions. Therefore, mechanisms to address crime and criminal organizations and their activities have been organized.

4. Interpol was established in January 1990 as the General Secretary of Organized Crime and has been entrusted with overseeing international policy on combating this crime by providing Member States with various information on criminal organizations, money laundering and suspects, whether individuals or bodies, and examining all problems and difficulties facing the control mechanisms. Furthermore, Interpol prepares studies on economic projects, on groups of persons who contribute to illegal activities, so as to establish criminal justice and enable employees to benefit from scientific development and the adoption of a unified plan. It assists developing national laws on a more inclusive and flexible approach in order to understand the specificity of this crime, removing obstacles to international cooperation and facilitating communication regarding the coordination of work. This is the first step ${ }^{34}$.

The second step is to encourage States to establish and operate a joint data bank on organized crime and its members and to collect information on convicted persons,

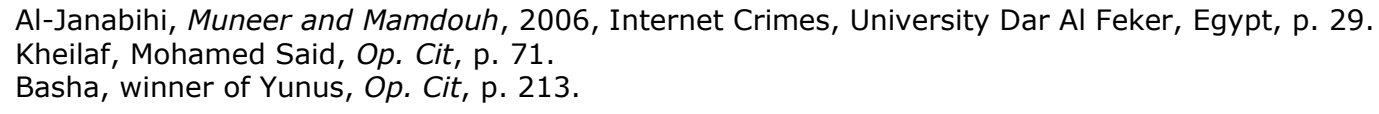


ensuring that legal files are as protected as they are in domestic and international law ${ }^{35}$. Each State Party shall take important and effective measures. We propose some examples in this regard, as follows:

i. Appointment of a central authority that communicates directly with the central authorities of the other States Parties to provide the support and assistance provided for in this Convention, including directing and receiving requests for support and assistance.

ii. To establish communication channels between its specialist authorities, departments and services to facilitate safe and rapid exchange of information on all aspects mentioned in these conventions. In addition, the draft Convention focused on cooperation during the gathering of inferences and investigation about:

a. Identifying persons suspected of having committed, and contributing to, the offenses covered by the Convention and their places of concentration and activity.

b. Identifying the movement of funds and property derived from the perpetration of any organized crime to ensure the effectiveness and rapidity of the proceedings. Creating joint teams is recommended to monitor the tracking of funds in each State Party to ensure the protection of the security of persons and operations.

The parties must recognize and understand that the cooperation process does not affect the sovereignty of the State whose territory was crossed to follow-up suspects or targeted funds and that they should take practical measures to ensure that their security services cooperate to monitor and detect material transfers. As previously explained, this is intended to be updated ${ }^{36}$.

The available audited database facilitates the cooperation of law enforcement authorities in exchanging data and detecting persons fleeing justice, as well as in exposing the methods that criminal organizations resort to recruit persons for trafficking purposes. In order to achieve the intended objectives, the following should be ensured:

A. Monitoring compliance of States Parties in the implementation of institutional arrangements and procedures established under the Convention. Developing mechanisms consistent with the development of scientific and technological knowledge.

B. Facilitating the exchange of information to counter transnational organized crime.

C. Assessing the scope of progress in achieving the objectives of the Convention and making recommendations on issues necessary for the implementation of the Convention and for the mobilization of financial resources ${ }^{37}$.

Accordingly, we conclude that the executive policy of the draft international conventions against crime and complementary protocols aims to strengthen cooperation among the criminal justice agencies and urges States to establish a common information center

35 Athena, Imad, Op. Cit, p. 106.

36 Commission on Crime Prevention and Criminal Justice, sixth session, draft United Nations Framework Convention against Organized Crime, p. 21.

37 Commission on Crime Prevention and Criminal Justice, sixth session, draft resolution IV against corruption and bribery in commercial and financial transactions, p.78 
benefiting from the latest information and communication technologies, run by highly competent persons. In addition, it proposes following-up criminal activities and investigating perpetrators to ensure a serious contribution according to model standards.

Furthermore, those involved should report on the challenges and factors that inhibit the implementation of the plans and programs they are working on. They also can request more information about criminal activities occurring within their territory and communicate their experiences through prevention and control measures.

In all cases, the Commission on Crime Prevention and Criminal Justice of the United Nations should make suggestions and general recommendations based on the information it receives from any party and transmit them to the States concerned. Article 20, entitled "Collecting and sharing information on organized crime" of the United Nations Convention against Crime states:

\begin{abstract}
"The Secretary undertakes, with the assistance of the United Nations Crime and Justice Research Institute and other organizations of the United Nations Crime Prevention and Criminal Justice Program, to collect and analyze public information and special research results on organized crime, and to prepare studies of global trends in organized crime and policies and measures to prevent and combat organized crime"138.
\end{abstract}

Accordingly, it can be said that the role played by the United Nations in the past in the implementation of the International Convention against Crime has turned it into a mere positive spectator who observes and make suggestions. Therefore, the international organization should enhance coordination between the involved agencies, to select the best mechanisms to combat organized crimes, and to establish a network of liaison officers to facilitate cooperation between States Parties. It should assist developing countries in the exchange of information and in bringing the views of local legislators closer to this point.

In this regard, the Commission on Crime Prevention and Criminal Justice stipulates that: Each State Party shall establish a domestic regulatory system to control the activity of financial institutions within the jurisdiction of that State with a view to deterring moneylaundering, as follows:

1. Issuing licenses for these institutions and conducting periodic inspections of their activities.

2. Eliminating bank secrecy laws that may impede the operation of money laundering monitoring programs in States Parties.

3. The institutions shall prepare clear and complete records of accounts and keep transactions in them or through them for at least five years and ensure that such records are available to the specialized authorities for use in criminal investigations and prosecutions in investigations.

38 Athena, Imad, Op. Cit, 88. \& Commission on Crime Prevention and Criminal Justice, eighth session, proposed program of work in the area of crime prevention and criminal justice. 
4. Ensuring that the information held by such institutions on the identity of customers and account holders is available to law enforcement authorities and the parties concerned. The States Parties shall notify all financial institutions of the opening of anonymous accounts or accounts under false names.

5. Obligating those institutions to report suspicious or unusual transactions.

The Jordan experience constitutes an example of combating cybercrime. Jordan issued the Electronic Crimes Act of 2015, which was amended in 2018 to add new forms of cybercrime and to tighten penalties for perpetrators. It also issued the Prevention and Combating Terrorism Act of 2006, but this law did not explicitly criminalize cyberterrorism. Additionally, the State security crimes are flexible enough to accommodate cyberterrorism. But after amendments made by the Jordanian legislator to the law in $2014^{39}$, it was considered prohibited terrorist acts.

The Jordanian law listed, in the text of Article 3, paragraph e, the use of the information system, the information network or any means of publication or media, or the establishment of a website to facilitate the commission of terrorist acts or to support a group or organization or an association that carries out terrorist acts, promotes its ideas or finances, or carries out any act that would expose the Jordanians or their property to the risk of acts of hostility or retaliation against them.

It is obvious that the Electronic Crimes Act of 2018 and the Jordanian Anti-Terrorism Act of 2014 referred to cybercrime in a general manner. Still, the national will works towards the development of specialized bodies and cadres that cooperate with the international criminal justice agencies to combat cybercrime, because national justice alone is not enough to combat these crimes. No regional bodies have been established to document the relationship with counterparts. This is done through an understanding between state governments and within the framework of criminal legality.

\section{Conclusion}

This study dealt with the adequacy of the international cooperation means for combating cybercrime and ways to modernize it. It is one of the most serious crimes of the modern era, and this is due to the continuous development of information technology and the electronic devices and networks that facilitate its progress. Thus, the study aimed to shed light on this problem and try to find solutions to confront it. It tried to clarify what the international and national community is doing to keep abreast of the rapid developments of information crimes and the modernization of mechanisms and methods of international security cooperation in order to combat cybercrime through participation in international agreements and conferences. However, the activation of this cooperation remains controversial because of the spread of the crime and its development at all international levels, which raises questions about the success of the current international mechanisms to combat transnational organized crime, the ways in which they are used and the obstacles that limit their effectiveness. This requires the development of specialized bodies to monitor the organized crime phenomenon and authority coordination.

39 Jordan Prevention of Terrorism Act No. 18 of 2014. 


\section{Results}

- Efforts to combat cybercrimes are not commensurate with the size of the means and techniques possessed by criminal organizations.

- The divergence of political and legal systems would lead to a failure in the mechanisms of international cooperation to combat cybercrime.

- The current international and regional conventions to combat cybercrime are inadequate and completely ineffective.

- The response to cybercrime follows a non-uniform policy among countries.

\section{Recommendations}

1) Establishing specialized agencies to confront cybercrime with the support of the United Nations to formulate an integrated theory that responds to technological development and ensures modernized cooperation mechanisms.

2) Filling the legislative gap in the digital environment magazines with the issuance of explanatory legislation notes, especially in the field of electronic crime, encompassing the substantive and procedural rules.

3) Reviewing the curriculum and the need to include IT and networks information, to recognize their advantages and risks.

4) Compelling Internet service providers to allocate part of their budget to awareness and guidance, how to use the Internet safely and support civil society initiatives in this direction.

5) Scientific planning to combat information crime and the need for countries to adopt a unified policy to address this crime. International convergence is the only way to confront cybercrime and address organized crime.

6) Expanding Arab cooperation in the field of combating cybercrime, like the Budapest Convention.

7) Updating the security organization by all scientific and technical means in order to detect and follow-up crimes, through the formation of a specialized unit to followup developments and put forward ways to combat them.

\section{References}

Arian, Mohamed Ali (2011). Computer Crimes, New University House, Alexandria University, Egypt, p. 25.

Athena, Imad (1991). "INTERPOL" in Conflict with Crime, I, Prepared House for Publishing, Syria.

Attia, Tarek Ibrahim (2009). Information Security - The Legal System of Information Protection, New University House, Egypt, p. 343.

Basha Faizah, Younus (2001). Organized crime under international conventions and national laws, Dar al-Nahda al-Arabiya, Egypt. 
Bassiouni, Mohamed Sherif (2004). Transnational Organized Crime, F1, Dar Al Shorouk, Egypt.

Darwish, Abdel Kareem (1997). Transnational Organized Crime, Knowledge facility, Egypt.

Ghareeb, Muhammed Eid (1988). "Explanation of the Penal Code «General Section»", General Theory of Crime, II, Dar Al-Ilm for millions, Lebanon.

Ghattas, Iskandar (s.d.). Arab Symposium on International Judicial Cooperation in the Criminal Field in the Arab World, Dar Al-Qalam, Lebanon.

Halabi, Khalid Ayad (2011). Investigation of Computer and Internet Crimes, Dar Thaqafa, Jordan, p.11.

Harouni, Hazem (1988). "International Judicial Appeal", National Journal, 3rd issue.

Hilali Abdullah Ahmed (2011). Budapest Convention on Combating Cyber Crime, Dar alNahda al-Arabiya, Egypt, p. 192.

Janabihi, Muneer and Mamdouh (2006). Internet Crimes, University Dar Al Feker, Egypt. Journal of Information Technology (2015). Department of Information Systems, Jordan. Kheilaf, Mohammed Said (1997). The Mythical Realistic Mafia, Dar Al-Afaq Publishing and Distribution, Morocco.

Laqli, Mahmoud Mustafa (1991). Judicial Links, University Library House, Egypt, p. 132.

Nabhan, Mohamed Farouk (1992). Towards a unified Arab strategy to fight organized crime, 1, University House, Jordan.

Omar Abul-Fotouh Abdel-Azim Hamami (s.d.). Criminal Protection of Electronic Information, Dar Al-Nahda Al-Arabiya, Egypt, p. 314.

Qahtani, Faleh Muflih (2008). Role of International Cooperation in Combating Overseas Drug Trafficking, Master Thesis, Naif Security University, p.12.

Qarzan Mustafa (2009). International politicians for combating Cyber Crime, published research on the legal organization of the Internet and cybercrime, University of Xi'an Ashour, University of Djelfa, p. 7.

Shawabkeh, Mohammed Amin (2004). Computer and Internet Crimes, Jordan, Dar Thaqafa for Publishing and Distribution, pp. 140-144

Sugheer, Jamil Abdel Baki (2001). Procedural Aspects of Internet Related Crimes, Dar al-Nahda, Egypt, 2001, p. 83.

Suleiman, Mohammed Ibrahim Mustafa (2006). Terrorism and Organized Crime, Dar Al Talai, Egypt, p.103.

Surour, Ahmed Fathi (1993). Mediator in Criminal Procedure Law, Cairo, Modern Printing House, I 7, Egypt, p.82.

Waly, Ali (1981). "Echoes of the Sixth United Nations Congress on the Prevention of Crime and the Treatment of Offenders", Journal of Justice, No. 27, issued by the Ministry of Justice, Abu Dhabi, p.146

Zuhair, Haj Tahir (2013). Mechanisms of Crime Prevention and Control, Master of Criminal Law, Faculty of Law, University of Algiers, Algiers, p. 95. 


\section{Conferences and documents}

1. Commission on Crime Prevention and Criminal Justice, sixth session, draft United Nations Framework Convention against Organized Crime.

2. Commission on Crime Prevention and Criminal Justice, sixth session, draft resolution IV against corruption and bribery in commercial and financial transactions.

3. Commission on Crime Prevention and Criminal Justice, eighth session, proposed program of work in the area of crime prevention and criminal justice,2001.

4. European Police Office website www.earopol.eu.in

5. International Criminal Police Organization website www.INTERPOL.int

6. 6 -Jordan Prevention of Terrorism Act No. 18 of 2014.

7. Proceedings of the Ministerial Conference on Organized Transnational Crime, Naples: Forms of more effective international cooperation in the prevention of transnational organized crime at the investigative level.

8. Proceedings of the Seventh United Nations Conference on the Prevention of Crime and the Treatment of Offenders, 1985.

9. Transparency International's website transparency.org

10. UN website www.un.org

11. United Nations Documents of the General Assembly, 51st Session, United Nations Declaration on Crime and Public Security, 1995.

12. Work of the Ad Hoc Committee on the Elaboration of a Convention against Transnational Organized Crime, fifth session, revised draft Protocol Supplementing the United Nations Convention against Transnational Organized Crime. 